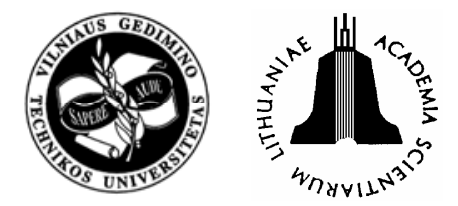

ISSN 1392-3730 print / ISSN 1822-3605 online

JOURNAL OF CIVIL ENGINEERING AND MANAGEMENT

http:/www.jcem.vgtu.lt

2006, Vol XII, No 2, 163-168

\title{
ESTIMATION OF THE EFFECTIVENESS OF RENOVATION WORK IN LITHUANIAN SCHOOLS
}

\author{
Rimidijus Pikutis ${ }^{1}$, Lina Šeduikyte் ${ }^{2}$ \\ ${ }^{1}$ Joint-Stock Company "Šiltas namas", A. J. Greimo g. 6, LT-10221 Vilnius, Lithuania. \\ E-mail: siltasnamas@takas.lt \\ ${ }^{2}$ Institute of architecture and construction of Kaunas University of Technology, Tunelio g. 60, \\ LT-3035 Kaunas, Lithuania. E-mail: lina.seduikyte@ktu.lt \\ Received 01 June 2005; accepted 12 Sept 2005
}

\begin{abstract}
The aim of this work was to estimate the effectiveness of the renovation work that was carried out in 63 Lithuanian schools by disclosing the main renovation works, analysing changes in the amount of the energy used for the heating after renovation. Reduction of the windows area with shields, replacement of old doors and windows with the new ones were the most frequent renovation works in the tested schools. $52 \%$ of respondents indicated condensation on windows after the renovation work. The indoor temperature of the schools increased from $15{ }^{\circ} \mathrm{C}$ to $18{ }^{\circ} \mathrm{C}$. Also, the energy consumptions for the heating of the schools was lowered by $17 \%$ in schools with district heating system and by $22 \%$ in schools with local boiler house.
\end{abstract}

Keywords: evaluation of renovation works, energy savings, school buildings.

\section{Introduction}

Many Lithuanian school buildings were constructed during the Soviet period, some even earlier. Most of these buildings have problems such as an excessive energy use for heating, windows that are not airtight when closed, defects in the external walls, moisture damage, indoor microclimate parameters which do not correspond to the hygienic norms etc. As the most of energy is consumed for the heating buildings, this point seems to be very important in respect of energy savings. Indoor air quality (IAQ), ventilation, an increased concentration of carbon dioxide $\left(\mathrm{CO}_{2}\right)$ and other contaminants, relative humidity (RH) as well as the thermal conditions inside the classrooms should be a matter of substance. Renovation work has been undertaken in school buildings in the last twelve years. A lot of organisational and technical problems arose together with this process.

\subsection{Investigations in schools}

Very few studies of the conditions in Lithuanian educational buildings have been made. Šeduikyte and Bliūdžius [1] made a field survey for determining whether the thermal parameters required by Lithuanian Hygienic Norms were being maintained in four typical auditoria of the Kaunas University of Technology, Lithuania. The results showed that temperature, relative humidity were not in compliance with the currently required thermal comfort conditions in auditoria with old sealed windows during the heating season. Insufficient natural ventilation resulted in a high carbon dioxide concentration in all auditoria.

A report presented by Stankevicius [2] discusses the present state of school buildings in Lithuania. The survey of thermal properties of building elements and general design characteristics are given. The authors indicated that the main types of complaints which concerned the indoor climate were low indoor temperature because of insufficient heat supply, large temperature differences at surfaces of external walls, draughts at windows, and a bad ventilation. A possible decrease in energy consumption and the order of improvements have been discussed.

The problem of insufficient ventilation resulting in high $\mathrm{CO}_{2}$ levels is common to educational buildings worldwide. The project report 'Indoor Air Pollution in School' by the European Federation of Asthma and Allergy Associations (EFA) provides information on the situation in the schools of 17 European countries, but no information about those in the Baltic countries, Poland, Bulgaria or Slovakia is given. The information provided by the researchers includes indoor air quality measurements, building characteristics and health problems that occur in them [3].

A study carried out in educational buildings in the USA by Angell and Daisey [4] listed three major categories of the encountered problem: inadequate ventilation systems (insufficient outdoor air was being supplied in $84 \%$ of schools), the pollutant source related problems and building or HVAC renovation related problems. 
Poor thermal environment can reduce the mental performance of schoolchildren, just as poor IAQ can. Studies by Wyon, Wargocki et al have shown that productivity is affected by IAQ [5-8]. In 1969, studies by D. P. Wyon and I. Holmberg showed that performance and behaviour in schools can be negatively affected by classroom temperature.

\subsection{Lithuanian school buildings}

A variation in number of schools and schoolchildren in Lithuania, presented by the Ministry of Education and Science, is shown in Fig 1.

Thermal resistance and technical properties of building enclosures in schools do not differ considerably from residential building characteristics. However, the total amount of the heat loss is higher in schools because of a lager windows area.

School buildings built until the Second World War usually were of ceramic brick masonry with sloped roofs and attics, with double - glazed windows in separate frames, wooden or concrete ceilings. During the renovation works of buildings of this period the change of windows is necessary as well as the insulation of attics. Buildings of the Soviet period have similar architecture and constructional solutions: massive external walls from ceramic or silicate brick masonry, cellular concrete or lightweight masonry and flat roofs. The building envelope usually has an inadequate area of windows.

The heating season in Lithuania usually starts and finishes when the average outside temperature in the run of three days is lower when $8{ }^{\circ} \mathrm{C}\left(10^{\circ} \mathrm{C}\right)$. The duration of the heating season depends on the region and can vary from 191 to 204 days when it starts at $8{ }^{\circ} \mathrm{C}$, and respectively from 214 to 226 days when the heating starts at $10{ }^{\circ} \mathrm{C}$.

The energy performance of buildings is a matter of great concern in Lithuania. Energy performance efficiency certifications for Lithuanian residential buildings are presented [9]. Proper evaluations of possible energy savings are discussed [10].

The aim of this work is to estimate the effectiveness of the renovation work that took part in 63 Lithuanian schools by disclosing the main renovation work, analysing changes in the amount of energy used for heating.

\section{Methods}

\subsection{The research object}

63 schools, located as equal as possible in three constructional climatic zones (11 schools in the Western region of Lithuania, 41 schools in the Central region (the biggest part) and 11 schools in the Eastern region) were chosen for this research. The deciding factors for choosing schools were as follows:

- renovation work in the heat substation or boiler room;
- replacement of old windows with the new ones (or renovation of the old ones), renovation of thermal insulation of walls and roof;

- implementation of more than one solution for heat energy savings, that is related to building constructions and engineering systems.

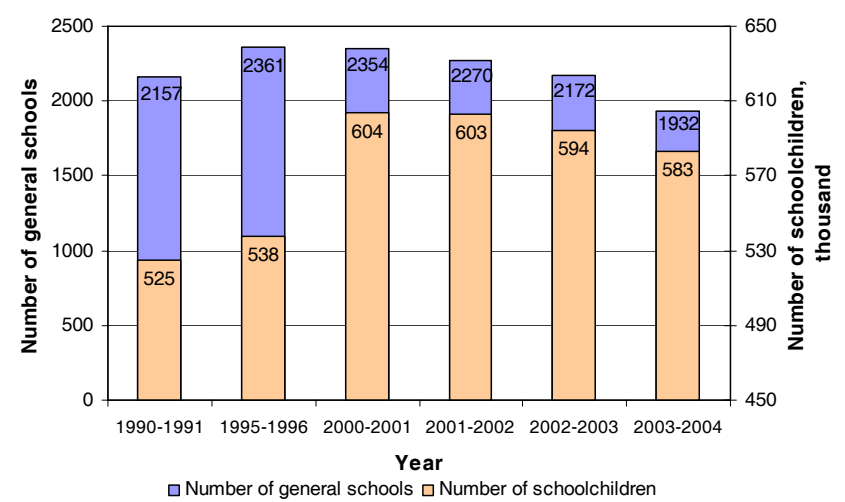

Fig 1. The variation of number of schools and schoolchildren in Lithuanian general schools

\subsection{The design of the database and questionnaires}

The estimation database was made from the existing design and inventory information by measuring physical parameters and using questionnaires.

The heat loss calculations as well as the evaluation of building service conditions were made by using approbated computer programs and visual evaluation methodologies.

The database contains information about the number of schoolchildren, heating supply system, the price of heating, general information about the building (the number of blocks and their area, the total area of the school, the total heated area, volume and height of the building, information about the roof and walls), the service characteristics of the building, technical information about the building, the heating characteristics of the building, the technical-insulation characteristics of building enclosures, energy input for building, the required energy and savings, the proposed renovation work, the main technical-economical parameters of the chosen project.

Questionnaires were provided to the personal of 28 tested schools. Questions were related to the changes which appeared after the renovation work completion.

They included condensation of replaced new plastic windows, moisture on walls and the mould on the inside surfaces, sufficient natural lightening after reducing windows area.

\subsection{Quantitative parameters}

Quantitative parameters were used for estimation. Quantitative parameters include:

1. Countable depreciation of the building.

2. Total investments for one square metre, which can be divided into two parts: 
- investments for implementing the heat energy savings,

- investments for better service characteristics of the building.

3. Energy savings, which are described by two parameters: energy savings in $\mathrm{kWh} / \mathrm{m}^{2}$ and energy savings expressed in percentage of heat energy used before renovation.

\subsection{Evaluation of energy used for heating and statistical analyses}

For the evaluation of energy used for the heating dependence on the outside temperature, data only of 52 investigated schools were used. The data of energy consumed for the heating includes energy used before the renovation (the heating season in 2000-2001) and energy used after the renovation (the heating season in 20012002). The inside temperature of the schools as well as the outside temperature were measured during the periods mentioned above.

For the comparison, energy used for heating was calculated for one square meter $\left(\mathrm{kWh} / \mathrm{m}^{2}\right)$. In order to compare energy consumption in different months, calculations for 30 days period were done.

Analyses of database segments, the significance of differences between the analyzed pairs of data were tested with statistical methods. T-test was used for the comparison of means for two case groups. After the implementation of some changes (in our case renovation works), the two-sample T-test was used to compare the average values of the tested parameter before and after changes.

\section{Results and discussion}

\subsection{The main renovation work undertaken in the tested schools}

Estimated quantitative parameters are presented in Table 1. Taking into account investments for one square metre most finances were budget for the heat savings in the school with local boiler house. Total investments were 1,6 times higher for the schools with local boiler house compared to the district heating.

Various renovation work was carried out in the schools for the heat energy savings and for the improvement of building service characteristics (Fig 2). The reduction of window area with shields, the replacement of old doors and windows with the new ones as well as the renovation of the old ones was the most frequent kind of renovation work undertaken in the tested schools.

Table 1. Estimation of economical and energy parameters of tested school buildings $(n=52)$

\begin{tabular}{|c|c|c|c|c|c|c|c|c|}
\hline \multirow[b]{2}{*}{$\begin{array}{l}\text { Heating } \\
\text { methods }\end{array}$} & \multirow[b]{2}{*}{ Index } & \multirow[b]{2}{*}{$\begin{array}{c}\text { Depreciation } \\
\text { of the } \\
\text { building, \% }\end{array}$} & \multicolumn{4}{|c|}{ Investments, LT } & \multirow[b]{2}{*}{$\begin{array}{l}\text { Energy } \\
\text { savings, } \\
\mathrm{kWh} / \mathrm{m}^{2}\end{array}$} & \multirow[b]{2}{*}{$\begin{array}{c}\text { Energy } \\
\text { savings, \% }\end{array}$} \\
\hline & & & $\begin{array}{l}\text { Total for } \\
1 \mathrm{~m}^{2}\end{array}$ & $\begin{array}{l}\text { For the heat } \\
\text { savings for } \\
1 \mathrm{~m}^{2}\end{array}$ & $\begin{array}{c}\text { For the } \\
\text { renovation of } \\
\text { building for } \\
1 \mathrm{~m}^{2}\end{array}$ & $\begin{array}{l}\text { Quota for one } \\
\text { schoolchild }\end{array}$ & & \\
\hline \multirow{2}{*}{$\begin{array}{l}\text { District } \\
\text { heating } \\
(\mathrm{n}=30)\end{array}$} & $\begin{array}{l}\text { Average } \\
\text { value }\end{array}$ & $34,21 \pm 23,88$ & $146,71 \pm 70,62$ & $148,12 \pm 66,95$ & $39,80 \pm 45,52$ & $883,60 \pm 557,96$ & $0,05 \pm 0,04$ & $31,92 \pm 11,94$ \\
\hline & Median & 26,20 & 138,55 & 146,78 & 24,36 & 746 & 0,06 & 33,66 \\
\hline \multirow[t]{2}{*}{$\begin{array}{l}\text { Local boiler } \\
\text { house }(n=22)\end{array}$} & $\begin{array}{l}\text { Average } \\
\text { value }\end{array}$ & $36,87 \pm 17,91$ & $231,93 \pm 142,54$ & $178,68 \pm 138,58$ & $45,11 \pm 36,77$ & $2446,45 \pm 2434,79$ & $0,09 \pm 0,09$ & $33,61 \pm 12,01$ \\
\hline & Median & 28,90 & 202,57 & 153,89 & 38,13 & 1407,52 & 0,08 & 33,96 \\
\hline
\end{tabular}

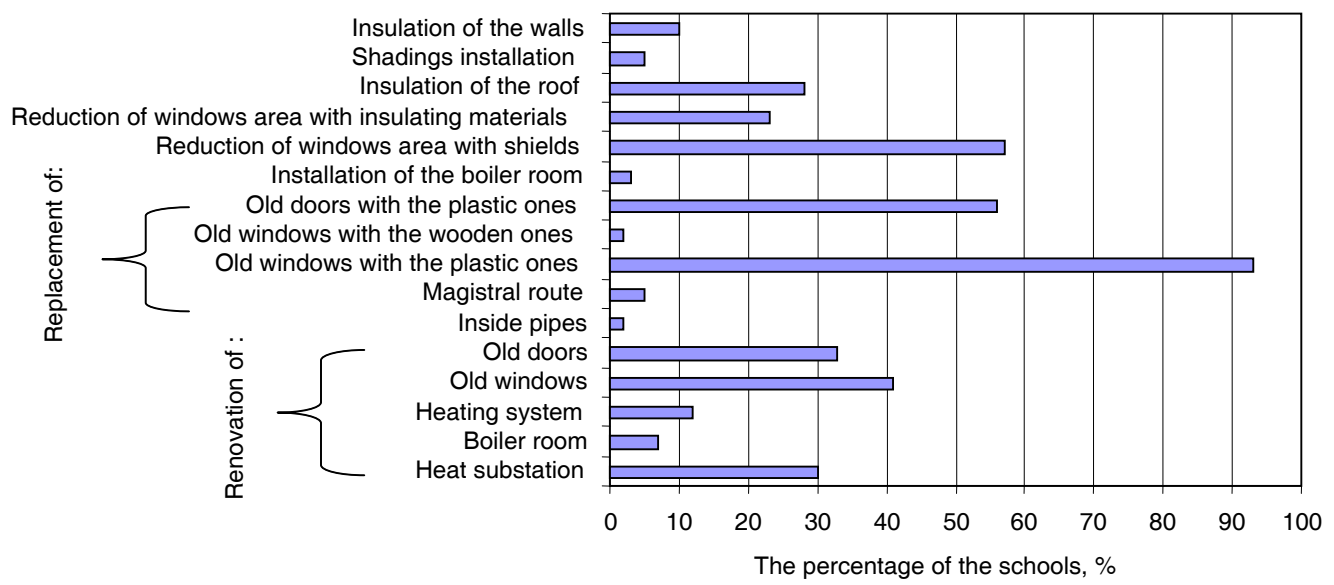

Fig 2. The distribution of the main renovation works in the schools 


\subsection{Questionnaires on the conditions after the renovation}

Results from the questionnaires of 28 tested schools are presented in Fig 3.

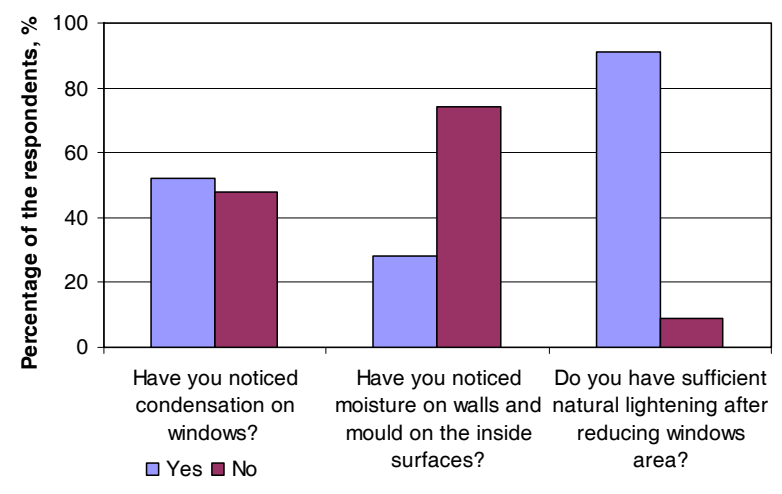

Fig 3. Results of the questionnaire survey

$52 \%$ of the research respondents indicated the condensation on windows after the renovation work. As the main emphasis was on the energy savings, other problems arose. New and very tight classroom windows with improper ventilation resulted in a higher water vapour indoor and condensation on windows. However, $28 \%$ of respondents indicated the moisture of walls and the growth of the mould on the inside surfaces. Taking into consideration the results of this survey, it could be stated that no problems with lightening arose after the reduction of window area.

\subsection{Energy used for the heating, depending on the outside temperature, before and after the renovation}

As the tested schools had district heating or heating by a local boiler house, the energy used for heating are presented separately for each system.

30 schools had district heating system. The average amount of energy for heating before renovation was $21,63 \pm 7,66 \mathrm{kWh} / \mathrm{m}^{2}$, and accordingly $18,52 \pm 7,42 \mathrm{kWh} / \mathrm{m}^{2}$ after the renovation. The variation coefficient is $36 \%$ of average value before the renovation and $40 \%$ after renovation. Empirical correlation coefficients show the average dependence $(\mathrm{P}<0,05)$, when correlation coefficient with the outside temperature is $-0,58$ before renovation, and accordingly $-0,49$ after it. The correlation coefficient with the difference of inside and outside temperature is 0,63 before and 0,54 after the renovation.

The variation of energy for heating in the schools with district heating system before and after the renovation are presented in Figs 4, 5.

When outside temperature was $0{ }^{\circ} \mathrm{C}$ energy used for the heating of schools with district heating was $21,9 \mathrm{kWh} / \mathrm{m}^{2}$ before renovation, meanwhile $18,28 \mathrm{kWh} / \mathrm{m}^{2}$ was needed after the renovation.
Approximation curves of energy used before and after the renovation depending on outside temperature are shown in Fig 6.

The average inside temperature in these schools was $15^{\circ} \mathrm{C}$ before the renovation and $18{ }^{\circ} \mathrm{C}$ after it.

Approximation curves of energy used before and after renovation depending on the difference between inside and outside temperatures are shown in Fig 7.

22 schools had heating with local boiler house. The average energy used for heating before renovation was $36,46 \pm 21,25 \mathrm{kWh} / \mathrm{m}^{2}$ and $28,15 \pm 15,92 \mathrm{kWh} / \mathrm{m}^{2}$ after renovation. The variation coefficient before renovation is $58 \%$ of average value before renovation and $69 \%$ after renovation. The correlation coefficient with outside temperature is 0,36 before renovation and $-0,26$ after it. Correlation coefficient with difference of inside and outside temperature is 0,43 before and 0,30 after renovation.

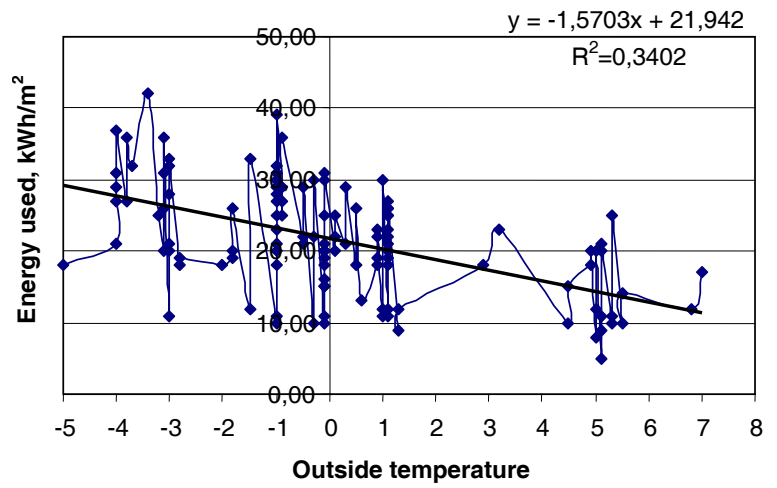

Fig 4. Energy used for heating ( 30 days period) of the schools with district heating before renovation

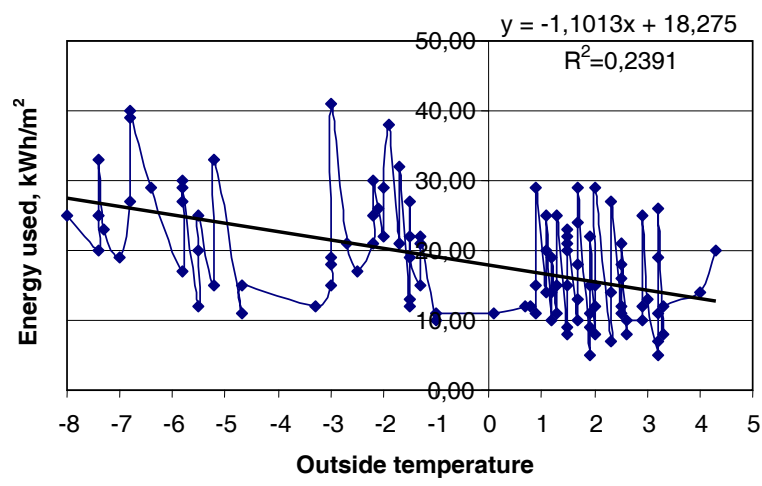

Fig 5. Energy used for heating (30 days period) of the schools with district heating after renovation

Schools with a local boiler house were using $60 \%$ more energy for the heating before renovation if compared with district heating system. After renovation $52 \%$ more energy was used in schools with local boiler house if compared with district heating.

The variation of energy used for heating in the schools with local boiler house before and after the renovation is presented in Fig 8-9. 


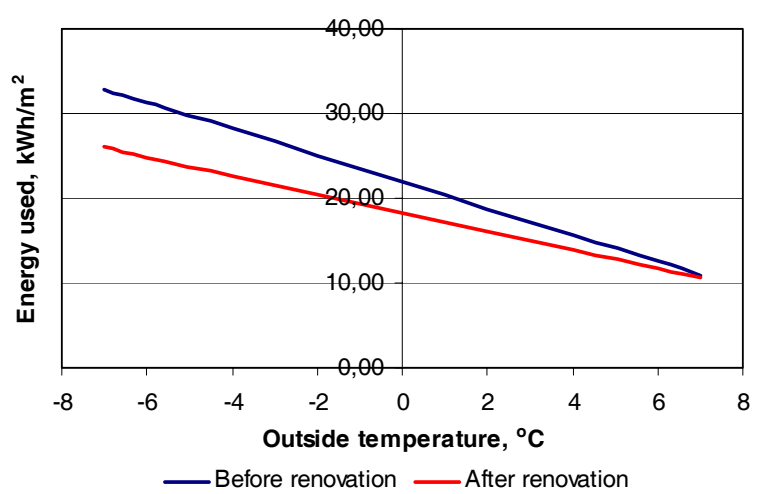

Fig 6. Approximation curves of energy used for heating depending on outside temperature before and after renovation in the schools with district heating

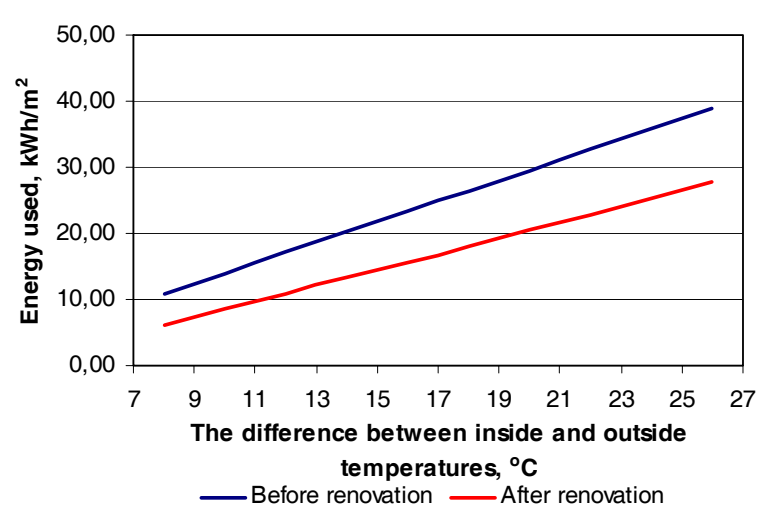

Fig 7. Approximation curves of energy used for heating depending on the difference between inside and outside temperatures before and after renovation in the schools with district heating

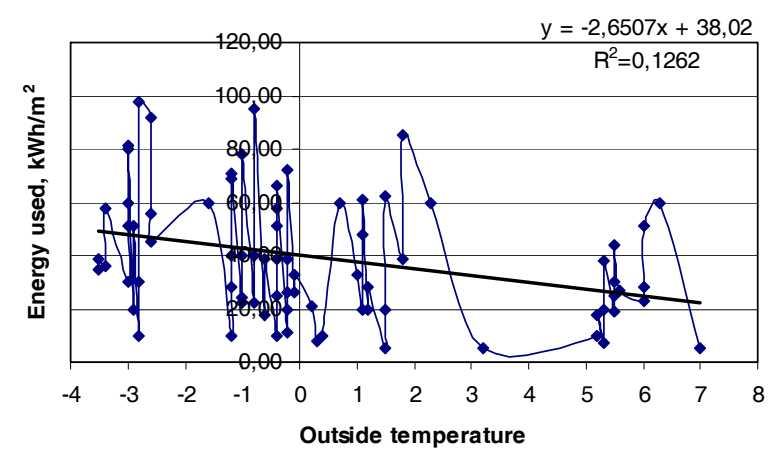

Fig 8. Energy used for heating ( 30 days period) of the schools with local boiler house before renovation

Approximation curves of energy used before and after the renovation depending on outside temperature are shown in Fig 10.

The average inside temperature in schools with local boiler house was $14,7^{\circ} \mathrm{C}$ before the renovation and $17,8^{\circ} \mathrm{C}$ after the renovation.

Approximation curves of energy used before and after renovation depending on the difference between inside and outside temperatures are shown in Fig 11.

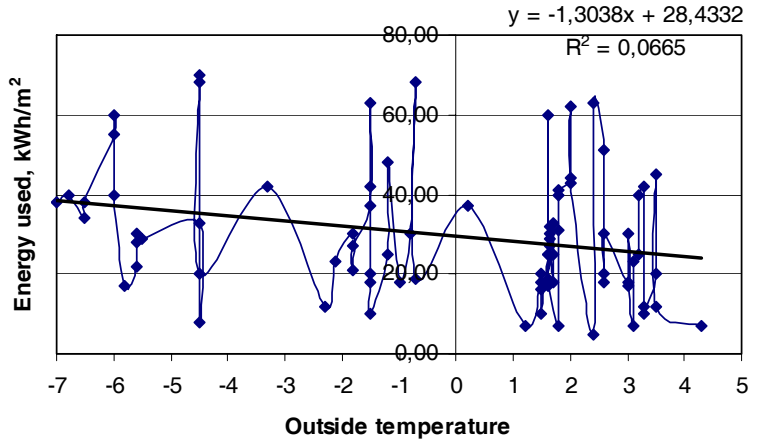

Fig 9. Energy used for heating (30 days period) of the schools with local boiler house after renovation

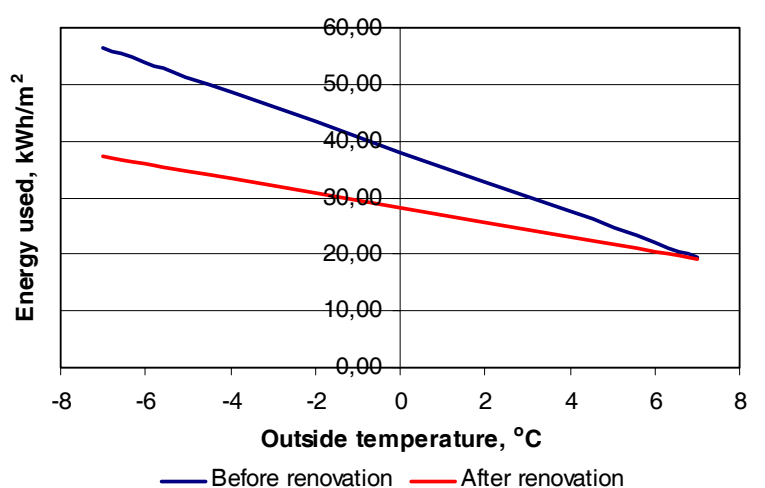

Fig 10. Approximation curves of energy used for heating depending on outside temperature before and after renovation in the schools with local boiler house

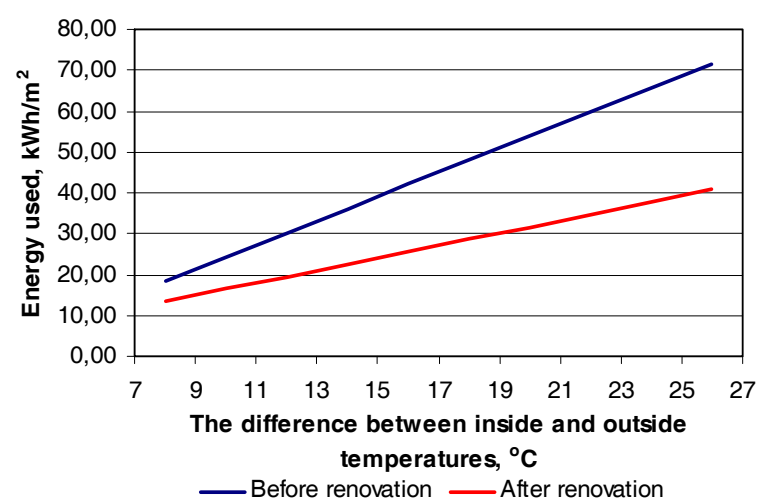

Fig 11. Approximation curves of energy used for heating depending on the difference between inside and outside temperatures before and after renovation in the schools with local boiler house

\section{Conclusions}

1. The average quota of investment in school renovations was $1510 \mathrm{Lt}$ for one schoolchild. The total investment consisted of $198,8 \mathrm{Lt} / \mathrm{m}^{2}$, from which $157,6 \mathrm{Lt} / \mathrm{m}^{2}$ were meant for the heat saving implementation and $41,2 \mathrm{Lt} / \mathrm{m}^{2}$ for the general renovation of school buildings.

2. The most frequent renovation work was the replacement of old windows with the new plastic ones. It occurred in $93,4 \%$ of all cases. The reduction 
of windows with shield constituted 57,4\%, the replacement of old doors with the plastic ones $55,7 \%$, the renovation of roof with insulation $-44,3 \%$.

3. The average temperature in schools with district heating increased by $3{ }^{\circ} \mathrm{C}$ and by $3,1^{\circ} \mathrm{C}$ in the case with local boiler house.

4. Results from the questionnaire survey showed that after renovation, when old windows were replaced with the new plastic ones, $52 \%$ of respondents indicated a condensation on new windows. $28 \%$ of respondents from 28 schools indicated the moisture of walls and the growth of mould on the inside surfaces after renovation.

5. The obtained results from statistical analyses indicated that energy consumption for heating schools with district heating system was $17 \%$ lower after the renovation.

6. The energy consumption for heating schools with local boiler house decreased by $22 \%$ after the renovation work was completed.

7. After renovation, energy for heating schools with local boiler house increased by $52 \%$ if compared with the centralised system.

\section{References}

1. Šeduikyte, L. and Bliūdžius, R. Estimation of thermal conditions in Lithuanian university auditoria and prediction of students performance. In: Proc of the 6th International Conference "Energy for buildings", Vilnius, Lithuania, 7-8 Oct, 2004. Ed. by E. Abel, V. Martinaitis, B. Todorovic, p. 511-517.

2. Stankevicius, V.; Karbauskaite, J.; Bliudzius, R. Energy audits and real implementation effect of energy saving measures in schools. In: Proc of the 2nd CTI/Industry joint seminar in Eastern Europe on technology diffusion and the IEA finance forum, Warsaw, Poland, 11-12 May, 2000, p. 74-79.
3. EFA report. Indoor Air Pollution in Schools. Finland, 2001, 178 p.

4. Angell, W. J., Daisey, J. Building factors associated with school indoor air quality problems: a perspective. In: Proc of 5th International Conference "Healthy Buildings", Vol 1, Washington DC, USA, 27 Sept. 3 Oct., 1997. p. 143-148.

5. Wargocki, P.; Wyon, D. P.; Sundell, J.; Clausen, G. and Fanger, P. O. The effects of outdoor air supply rate in an office on Perceived Air Quality, Sick Building Syndrom (SBS) symptoms and productivity. Indoor Air, Vol 10, No 4, 2000, p. 222-236.

6. Bako-Biro, Z.; Wargocki, P.; Weschler, C. J. and Fanger, P. O. Effects of pollution from personal computers on perceived air quality, SBS symptoms and productivity in offices. Indoor Air, Vol 14, No 3, 2004, p. 178-187.

7. Myhrvold, A. N.; Olsen, E. and Lauridsen, O. Indoor environment in schools - pupils' health and performance in regard to $\mathrm{CO}_{2}$ concentrations. In: Proc of the 6th International Conference on indoor air quality and climate, Vol 4, Nagoya, Japan, 21-26 July, 1996, p. 369-374.

8. Kajtar, L.; Herczeg, L. and Lang, E. Examination of influence of $\mathrm{CO}_{2}$ concentration by scientific methods in the laboratory. In: Proc of the 7th International Conference "Healthy Buildings", Singapore, 7-11 Dec. 2003. Ed. by Tham Kwok Wai, Sekhar C., Cheong D. CD version, p. 176-181.

9. Juodis, E.; Jablonska, B.; Uyterlinde, M. A.; Kaan, H. $F$. and van Wees M. T. Indicators for energy performance efficiency certification in the Lithuanian residential buildings. Journal of Civil Engineering and Management, Vol 9, No 2, 2003, p. 92-97.

10. Čiuprinskas, K. and Martinaitis, V. Correction of a designed building's heat balance according to its real heat consumption. Journal of Civil Engineering and Management, Vol 9, No 2, 2003, p. 98-103.

\section{LIETUVOS MOKYKLOSE ATLIKTU RENOVACIJOS DARBU EFEKTYVUMO ANALIZE் \\ R. Pikutis, L. Šeduikytė}

Santrauka

Daugumoje sovietiniais laikais ar net anksčiau pastatytų Lietuvos mokyklų susiduriama su įvairiomis problemomis. Jos susijusios su per dideliu energijos naudojimu šildymui, išorinėse sienose esančiais defektais, besikaupiančia drègme, nesandariais langais, patalpų mikroklimato parametrais, neatitinkančiais higieninių normų, ir pan.

Buvo atlikta 63 Lietuvos mokyklose ivvykdytų renovacijos darbų analizè. Ivvertintas šilumos energijos sunaudojimas prieš ir po renovacijos parodè, kad mokyklose su centralizuotu šildymu energijos sąnaudos sumažejo $17 \%$, o su vietiniu - $22 \%$. Dažniausiai pasitaikantys renovacijos darbai tirtose mokyklose buvo langu ploto mažinimas, senų durų, langu pakeitimas naujais. Po renovacijos mokyklose temperatūra vidutiniškai pakilo nuo $15{ }^{\circ} \mathrm{C}$ iki $18{ }^{\circ} \mathrm{C}$. Po atliktos renovacijos $52 \%$ apklausoje dalyvavusių respondentų ( 28 mokyklų darbuotojai) nurodè, kad po atliktų renovacijos darbų buvo pastebima vandens kondensacija ant langų paviršiaus.

Reikšminiai žodžiai: renovacijos darbų îvertinimas, energijos taupymas, mokyklų pastatai.

Rimidijus PIKUTIS. PhD, director of UAB „Šiltas namas“. The main research areas include analyses of energy consumption, audits in Lithuanian schools, physical properties of buildings and building materials.

Lina ŠEDUIKYTĖ. Junior Researcher at Institute of Architecture and Construction of Kaunas University of Technology, Lithuania. Her research interests include thermal-comfort parameters, pollutants emission from building materials, effects of indoor air quality on health, SBS symptoms and people performance. 